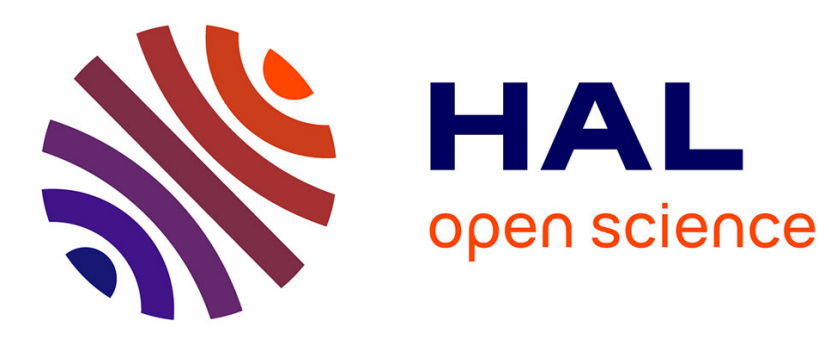

\title{
Selective Catalytic Oxidation of Diglycerol
}

Huan Wang, Nam Duc Vu, Guo-Rong Chen, Estelle Métay, Nicolas Duguet,

Marc Lemaire

\section{To cite this version:}

Huan Wang, Nam Duc Vu, Guo-Rong Chen, Estelle Métay, Nicolas Duguet, et al.. Selective Catalytic Oxidation of Diglycerol. Green Chemistry, 2021, 23 (3), pp.1154-1159. 10.1039/D0GC03239E . hal03252511

\section{HAL Id: hal-03252511 \\ https://hal.science/hal-03252511}

Submitted on 7 Jun 2021

HAL is a multi-disciplinary open access archive for the deposit and dissemination of scientific research documents, whether they are published or not. The documents may come from teaching and research institutions in France or abroad, or from public or private research centers.
L'archive ouverte pluridisciplinaire HAL, est destinée au dépôt et à la diffusion de documents scientifiques de niveau recherche, publiés ou non, émanant des établissements d'enseignement et de recherche français ou étrangers, des laboratoires publics ou privés. 


\title{
Selective Catalytic Oxidation of Diglycerol
}

\author{
Huan Wang, ${ }^{a}$ Nam Duc Vu, ${ }^{a}$ Guo-Rong Chen, ${ }^{b}$ Estelle Métay, ${ }^{a}$ Nicolas Duguet, ${ }^{* a}$ Marc Lemaire*a
}

The selective oxidation of $\alpha, \alpha$-diglycerol was studied using oxygen as a clean oxidant in the presence of a palladium / neocuproine complex. After optimization of the reaction parameters, the mono-oxidation product was obtained with $93 \%$ NMR yield (up to $76 \%$ isolated yield). The product was named "diglycerose" considering that it mainly exists as a cyclic hemi-ketal form.

The transformation of renewable biomass to added-value compounds is currently the subject of intense research efforts. ${ }^{1}$ Biomass represents an important reservoir of polyols as it is mainly composed of starch, cellulose, hemi-cellulose, sucrose, and many more oxygenated compounds. ${ }^{1,2}$ Even triglycerides, which exhibit a low oxygen content, are incorporating a polyol as a linker of fatty chains. Transesterification of triglycerides, extracted from vegetable oils, affords fatty acid methyl esters that are used as either biodiesel, ${ }^{3}$ starting materials for oleochemicals ${ }^{4}$ or biopolymers. ${ }^{5}$ Glycerol is obtained as the main coproduct of the methanolysis of vegetable oils and is valorized along its own value chain. It could be directly used as a renewable solvent ${ }^{6}$ or as a monomer for the production of bio-based polyesters. ${ }^{7}$ Glycerol is also an excellent platform molecule to prepare a wide range of biobased chemicals ${ }^{8}$ such as acrolein, ${ }^{9}$ glyceric acid, ${ }^{10} 1,2$-propanediol, ${ }^{11}$ among others. ${ }^{8}$ Moreover, it can be transformed to glycerol carbonate, ${ }^{12}$ solketal $^{13}$ and 1,2,3-trimethoxypropane, ${ }^{14}$ that serve as biobased solvents. ${ }^{15}$ Glycerol can also be used as a polar head in the preparation of renewable surfactants based on esters, ${ }^{16}$ acetals ${ }^{17}$ or ethers. ${ }^{18}$ In contrast, the chemistry of diglycerol is comparatively underdeveloped.

Diglycerol is a derivative of glycerol that is formally the result of the condensation of two molecules of glycerol. It is mainly prepared by direct oligomerization of glycerol. ${ }^{19}$ Diglycerol can be directly used as a monomer for the preparation of polyesters. ${ }^{20}$ Moreover, it can be converted to diglycerol dicarbonate (DGDC), ${ }^{21}$ that is further used as a building-block for the synthesis of polyhydroxyurethanes (PHUs). ${ }^{22}$ Diglycerolbased surfactants can be also produced such as diglycerol esters, ${ }^{23}$ acetals, ${ }^{24}$ and ethers. ${ }^{18}$ Other ether derivatives can be also prepared by dehydrogenative arylation ${ }^{25}$ or permethylation $^{26}$ to give hydrotropes and solvents, respectively.

The selective oxidation of polyols, especially those incorporating a 1,2-diol motif, provides $\alpha$-hydroxyketones, that are encountered in natural products and serve as useful synthetic intermediates. ${ }^{27}$ The oxidation of 1,2-diols to $\alpha$ hydroxyketones is a challenging task considering that many byproducts (e.g., 1,2-diketones, aldehydes, carboxylic acids) could be formed by over-oxidation and $\mathrm{C}-\mathrm{C}$ cleavage. Some selective methods were first reported using stoichiometric oxidants such as dioxiranes ${ }^{28}$ or $\mathrm{Br}_{2} \cdot{ }^{29}$ Catalytic methods were also developed based on $\mathrm{Ru}^{30}$ and Ni-catalyzed dehydrogenation. ${ }^{31}$ Particularly, Waymouth et al. have reported a highly selective catalytic method for the oxidation of glycerol to dihydroxyacetone with a palladium / neocuproine complex using hydroquinone as an oxidant. ${ }^{32}$ The method was further developed using oxygen (or air) and applied to erythritol ${ }^{33}$ and other polyols, ${ }^{34}$ and even carbohydrates. ${ }^{35}$ However, to the best of our knowledge, the selective catalytic oxidation of diglycerol has never been reported.

In this context, we report here a selective catalytic method for the mono-oxidation of diglycerol using oxygen as a clean oxidant.

Diglycerol is usually produced by oligomerization of glycerol, resulting in the formation of 3 main isomers. ${ }^{19}$ The proportion of each isomer in commercially available diglycerol was found to be $\sim 80 \%$ for $\alpha, \alpha$-isomer, $\sim 20 \%$ for $\alpha, \beta$-isomer and $<1 \%$ for 6,6-isomer, as determined by ${ }^{13} \mathrm{C}$ NMR. The oxidation of diglycerol already offers a great challenge in term of regioselectivity but also in term of mono- versus multiple oxidations. So, in order to have a simpler model for oxidation of diglycerol, the purification of the crude starting material was carried out through the formation of $\alpha, \alpha$-diglycerol dicarbonate 2 (Fig. S1 in ESI). ${ }^{36}$

The selective mono-oxidation of the $\alpha, \alpha$-isomer of diglycerol $\alpha, \alpha-1$ was performed with palladium-based catalysts using oxygen as a clean oxidant in acetonitrile/water $(10: 1)$ at $30^{\circ} \mathrm{C}$ (Table 1).

Table 1. Oxidation of (di)glycerol with palladium-based catalysts. ${ }^{a}$

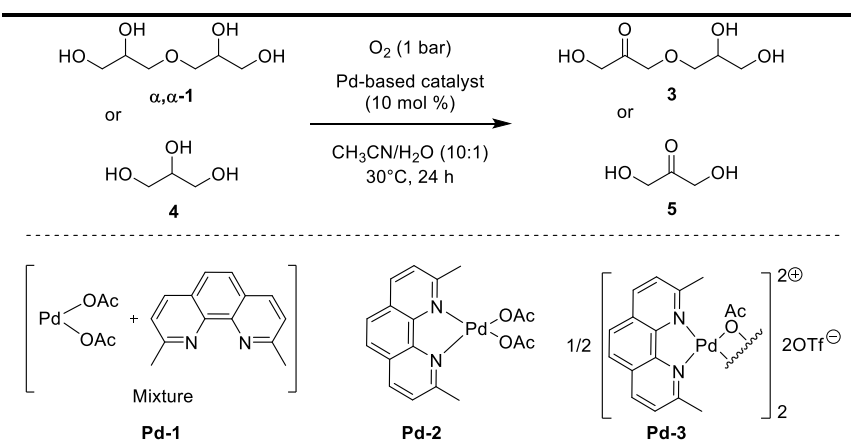

\begin{tabular}{llll}
\hline entry & catalyst & Yield of $\mathbf{3}(\%)^{b}$ & Yield of $\mathbf{5}(\%)^{b}$ \\
\hline 1 & Pd-1 & 0 & 41 \\
2 & Pd-2 & 0 & 60 \\
3 & Pd-3 & trace & $>90$
\end{tabular}

a Reaction conditions: $\alpha, \alpha$-diglycerol or glycerol $(0.45 \mathrm{mmol})$, Palladium-based catalyst Pd1-3 (10 mol\%), $\mathrm{O}_{2}$ (1 bar), $\mathrm{CH}_{3} \mathrm{CN} / \mathrm{H}_{2} \mathrm{O}$ (v/v 10:1, $5.5 \mathrm{~mL}$ ), 30 ${ }^{\circ} \mathrm{C}, 24 \mathrm{~h} .{ }^{b}$ Yields were determined by ${ }^{1} \mathrm{H}$ NMR. 
First, no oxidation product was obtained when using either a mixture of $\mathrm{Pd}(\mathrm{OAc})_{2}$ and neocuproine Pd-1 or a preformed ${ }^{37}$ $\mathrm{Pd}(\mathrm{OAc})_{2}$ /neocuproine complex Pd-2 (Table 1, entries 1-2). In these two cases, the starting material was recovered unaltered. These results were somewhat surprising since the same catalysts gave good results for the oxidation of glycerol 4 and the corresponding dihydroxyacetone $\mathbf{5}$ was obtained with 41 and $60 \%$ yield, respectively (Table 1, entries 1-2). With Pd-3 complex, prepared following a reported method, ${ }^{38}$ only trace amounts $(<5 \%)$ of the mono-oxidation product of diglycerol was observed (Table 1, entry 3 ). Once again, the same catalyst performed very well for the oxidation of glycerol and dihydroxyacetone $\mathbf{5}$ was obtained with $90 \%$ yield (Table 1, entry 3). From these results, it is striking to see that the reported palladium-based catalysts exhibit good catalytic activities for the oxidation of glycerol while they are completely ineffective for diglycerol. We hypothesized that the poor solubility of diglycerol under the chosen reaction conditions was responsible for the poor conversion.

To solve this problem, the proportion of water was increased to promote the dissolution of diglycerol and $\mathrm{CH}_{3} \mathrm{CN} / \mathrm{H}_{2} \mathrm{O}(\mathrm{v} / \mathrm{v}$ 7:1) was selected as solvent system for further optimization. Then, the temperature was gradually increased from 30 to $80^{\circ} \mathrm{C}$ (Fig. S2 in ESI). The best result was obtained at $70^{\circ} \mathrm{C}$ with an isolated yield of $27 \%$ for the mono-oxidation product $\mathbf{3}$, accompanied with about $11 \%$ yield of the bis-oxidation product 6 . Increasing the temperature to $80^{\circ} \mathrm{C}$ did not improve the results. On the contrary, very low yields were obtained under these conditions. This was attributed to the catalyst deactivation with the formation of $\mathrm{Pd}(0)$ aggregates, i.e. "Pd black". 38

From the ${ }^{1} \mathrm{H}$ NMR spectrum, it was found that the expected product $\mathbf{3}$ exists as an open and a cyclic form, representing 7 and 93\%, respectively (Scheme 1). Indeed, compound $\mathbf{3}$ cyclizes to form a six-membered ring as a single diastereoisomer. The relative cis configuration between the two hydroxymethyl groups was determined by NMR analyses after derivatization (see ESI). The formation of a sevenmembered ring system has not been detected, such product being usually highly disfavored. Product $\mathbf{3}$ has been named "diglycerose" due to its structural similarities with ketoses.
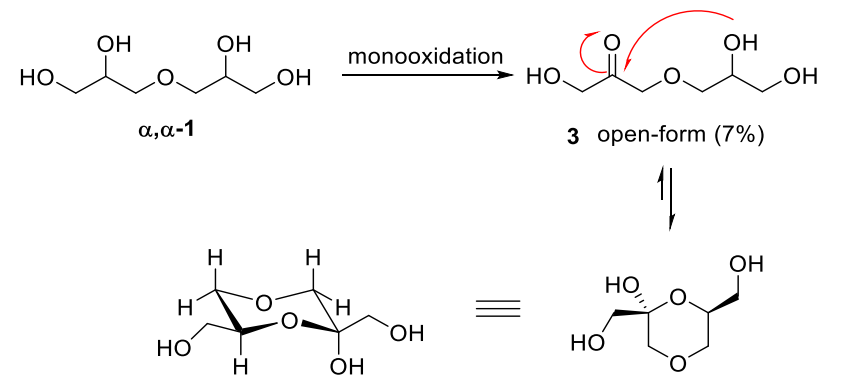

Scheme 1. Mono-oxidation product of diglycerol.

Next, various solvents were screened. The temperature was set at $50^{\circ} \mathrm{C}$ to limit the formation of palladium black and the time was limited to 2 hours to avoid the formation of the bisoxidation product 6 (Table 2). First, repeating the reaction in
$\mathrm{CH}_{3} \mathrm{CN} / \mathrm{H}_{2} \mathrm{O}(7: 1)$ in 2 hours gave only $5 \%$ yield (Table 1 , entry 1). Protic polar solvents such as $\mathrm{MeOH}$ and $\mathrm{EtOH}$ did not lead to any conversion of the starting material. Ethereal solvents were next screened. No reaction was obtained when using CPME and 2-MeTHF while the product was formed in THF and 1,4-dioxane with 31 and $43 \%$ yield, respectively (Table 1, entries 2-5). Then, fluorinated solvents were tested as they are known to well dissolve oxygen. ${ }^{39}$ (Trifluoromethyl)benzene was first used but no reaction was observed (Table 1, entry 6). Satisfyingly, when using TFE and HFIP, diglycerose $\mathbf{3}$ was obtained with 54 and 74\%, respectively (Table 1, entries 7-8). The success of HFIP has been reported in numerous occasions ${ }^{40}$ in homogeneous catalysis using transition metals, ${ }^{41}$ notably in $\mathrm{CH}$ activation. ${ }^{42}$ In our case, the use of HFIP could increase the oxygen solubility but it could also increase catalyst lifetime. Indeed, Waymouth has shown that phenol derivatives can increase the lifetime of $\mathrm{Pd} /$ neocuproine complexes. ${ }^{38}$ So, considering that HFIP exhibits a similar pKa (9.3) as phenol, it is likely that it also helps to prevent the catalyst degradation.

Table 2. Oxidation of $\alpha, \alpha$-diglycerol in different solvent systems. ${ }^{a}$

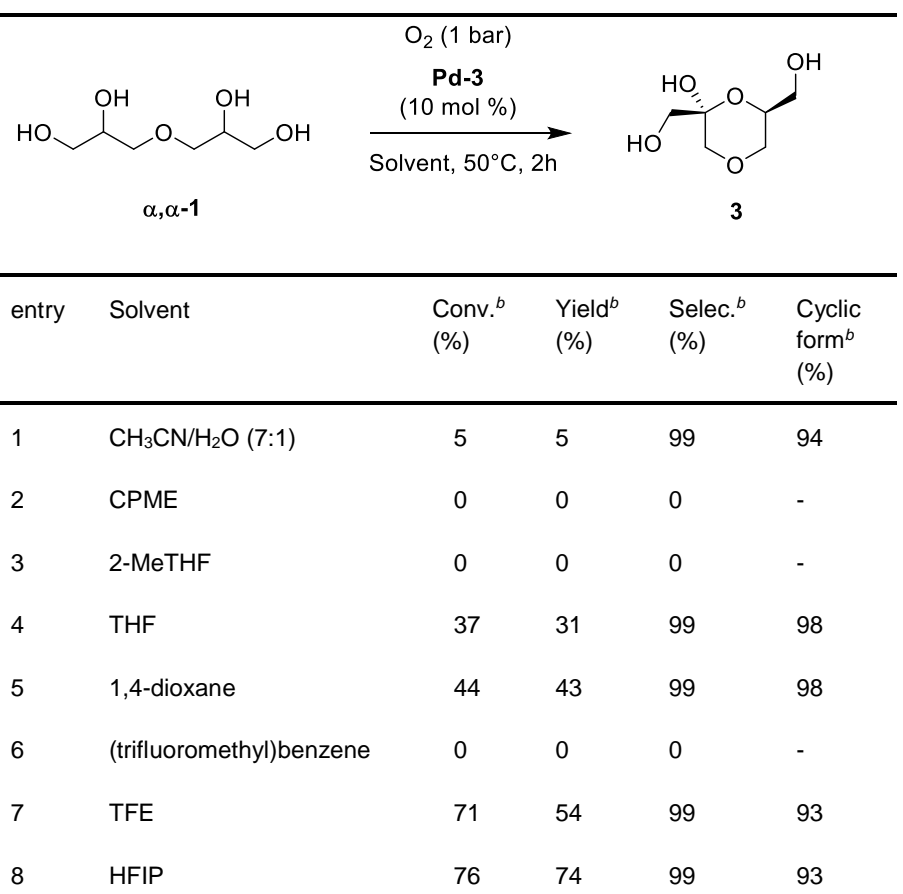

a Reaction conditions: $\alpha, \alpha$-diglycerol $\left(0.45 \mathrm{mmol}\right.$ ), Pd-3 (10 mol\%), $\mathrm{O}_{2}$ (1 bar), solvent $(5.5 \mathrm{~mL}), 50^{\circ} \mathrm{C}, 2 \mathrm{~h} .{ }^{b}$ Conversion, yield, selectivity and ratio of monooxidation product on cyclic form were determined by ${ }^{1} \mathrm{H}$ NMR using mesitylene as internal standard. CPME: cyclopentyl methyl ether, 2-MeTHF: 2-methyl tetrzhydrofuran, THF: tetrahydrofuran, TFE: trifluoroethanol, HFIP: 1,1,1,3,3,3Hexafluoroisopropanol.

Consequently, HFIP was selected for further optimization (Table 3). Increasing the oxygen pressure to 3 and 6 bar, led to a complete conversion and diglycerose 3 was obtained with 89 and $94 \%$ yield, respectively (Table 3 , entries 1-2). Satisfyingly, the selectivity for the mono-oxidation product remained high (around 98\%), highlighting the high selectivity of the catalytic system. Considering that palladium is an expensive metal, the amount of catalyst should be reduced. The reaction was first carried out with 5 mol\% of catalyst under 3 or 6 bar of oxygen. 
Under these conditions, compound 3 was obtained with 66 and $63 \%$ yield (Table 3, entries 3-4). Further decreasing the catalyst loading to 2.5 mol\%, only gave $33 \%$ yield (Table 3, entry 5). Recently, it was shown that additives such as phenol or styrene have a beneficial impact on the catalyst activity and lifetime. ${ }^{38}$ In our case, in the presence of styrene ( 5 equiv) with 2.5 mol\% catalyst loading, the yield increased to $75 \%$ (Table 3, entry 6). Increasing the reaction time to 18 hours allowed to reach full conversion and $\mathbf{3}$ was obtained with 93\% yield (Table 3 , entries 7-8). Further decreasing the catalyst loading to 1 mol\% did not allow to reach high yield, even with extended reaction time (Table 3, entries 9-10). Finally, the oxidation of diglycerol was repeated using catalytic systems Pd-1 and Pd-2 under the optimized conditions. In that case, diglycerose $\mathbf{3}$ was only formed with 51 and $60 \%$ yield, respectively (Table 3, entries 11-12). These experiments show that all catalytic systems are active under the optimized conditions, which are found to be crucial for the success of this reaction. The trend between the three different catalytic systems is the same than the one observed for the oxidation of glycerol (Table 1), with Pd-3 complex being the most active catalyst. The superiority of this cationic palladium (II) complex in the oxidation of alcohols has been previously attributed to the presence of both the acetate and triflate ions. ${ }^{43}$

Table 3. Diglycerol oxidation in HFIP

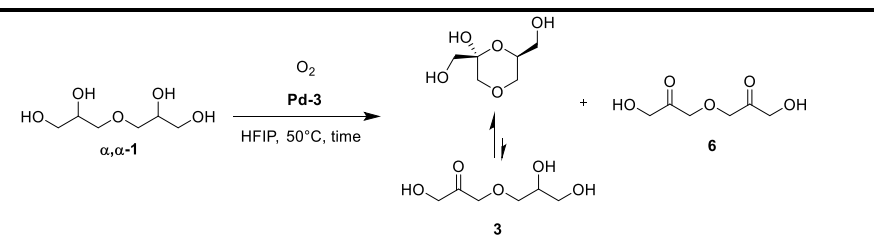

\begin{tabular}{|c|c|c|c|c|c|c|}
\hline $\begin{array}{l}\text { Entr } \\
y\end{array}$ & $\begin{array}{l}\mathrm{O}_{2} \\
\text { (bar) }\end{array}$ & $\begin{array}{l}\text { Catalyst } \\
(\mathrm{mol} \%)\end{array}$ & $\begin{array}{l}\text { Time } \\
\text { (h) }\end{array}$ & $\begin{array}{l}\text { Conv. } \\
(\%)\end{array}$ & $\begin{array}{l}\text { Yield }^{b} \\
(\%)\end{array}$ & $\begin{array}{l}\text { Selec. }{ }^{b} \\
(\%)\end{array}$ \\
\hline 1 & 3 & 10 & 2 & 95 & 89 & 98 \\
\hline 2 & 6 & 10 & 2 & $>99$ & 94 & 98 \\
\hline 3 & 6 & 5 & 2 & 69 & 66 & 99 \\
\hline 4 & 3 & 5 & 2 & 69 & 63 & 99 \\
\hline 5 & 3 & 2.5 & 2 & 34 & 33 & 99 \\
\hline $6^{c}$ & 3 & 2.5 & 2 & 79 & 75 & 99 \\
\hline $7^{c}$ & 3 & 2.5 & 6 & 79 & 77 & 99 \\
\hline $8^{c}$ & 3 & 2.5 & 18 & $>99$ & $93(61)^{d}$ & 98 \\
\hline $9^{c}$ & 3 & 1 & 18 & 77 & 74 & 99 \\
\hline $10^{c}$ & 3 & 1 & 30 & 77 & 73 & 99 \\
\hline $11^{c, e}$ & 3 & 2.5 & 18 & 54 & 51 & 99 \\
\hline $12^{c, f}$ & 3 & 2.5 & 18 & 64 & 60 & 99 \\
\hline \multicolumn{7}{|c|}{$\begin{array}{l}{ }^{a} \text { Reaction conditions: } \alpha, \alpha \text {-diglycerol }(0.45 \mathrm{mmol}), \mathrm{Pd}-3, \mathrm{O}_{2}, \mathrm{HFIP}(5.5 \mathrm{~mL}), 50^{\circ} \mathrm{C} \\
\text { unless otherwise stated. }{ }^{b} \text { Conversion, yield, selectivity and ratio of mono- } \\
\text { oxidation product ( } 3 \text { Versus } 6 \text { ) were determined by }{ }^{1} \mathrm{H} \text { NMR using mesitylene as } \\
\text { internal standard. }{ }^{c} \text { Styrene ( } 2.25 \mathrm{mmol}, 5 \text { equiv) was added. }{ }^{d} \text { Isolated yield in } \\
\text { brackets. }{ }^{e} \text { Using Pd-1. }{ }^{~} \text { Using Pd-2. }\end{array}$} \\
\hline
\end{tabular}

While the non-coordinating triflate ion generates an open coordination site that allows fast initial rates, ${ }^{44}$ the acetate ion acts as an internal base that facilitates the intramolecular deprotonation. ${ }^{45} \mathrm{~A}$ scale-up reaction was performed on a 10fold scale under optimized conditions and diglycerose $\mathbf{3}$ was obtained with $76 \%$ isolated yield (Scheme 2 ).

Scheme 2. Scale-up reaction for $\alpha, \alpha$-diglycerol.

The oxidation method was found to be efficient and selective on $\alpha, \alpha$-diglycerol. Therefore it could also be applied to $\alpha, \beta$-diglycerol. However, $\alpha, \beta$-diglycerol recovered from the filtrate after hydrolysis of diglycerol dicarbonate was not pure enough. Consequently, it was prepared in three steps from solketal following a reported procedure (see ESI for details). ${ }^{46}$ Selective oxidation of $\alpha, \beta$-diglycerol was also carried out under the optimized conditions. In that case, the monooxidation product 7 was only obtained with $4 \%$ yield and bicylic ketal $\mathbf{8}$ - formed by dehydration of $\mathbf{7}$ - was obtained with $76 \%$ yield (Scheme 3). Satisfyingly, reducing the $\mathrm{O}_{2}$ pressure to 1 bar gave 7 with 51\% isolated yield. $\alpha, \beta$-Diglycerose 7 also exists as a cyclic hemi-ketal (no open formed detected) and was obtained with a dr of 88:12. In the major diastereoisomer, the hydroxymethyl groups adopt a relative trans configuration (determined by NMR, see ESI).

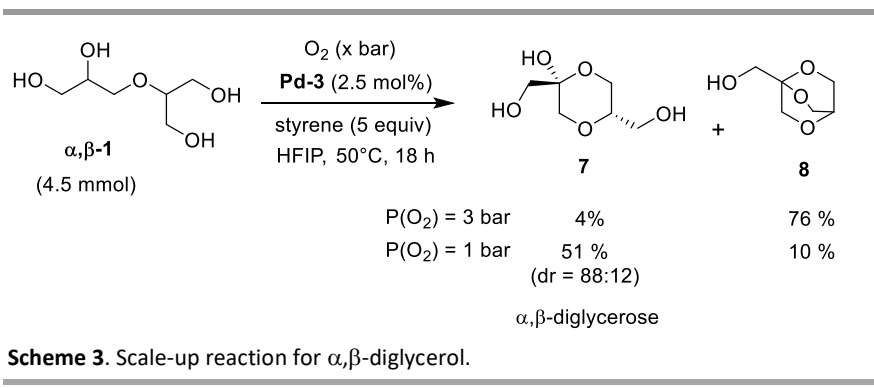

The difference of reactivity between $\alpha, \alpha$ - and $\alpha, \beta$-diglycerol led us to investigate their oxidation rates under the optimized conditions. The oxidation was first performed under 1 bar of $\mathrm{O}_{2}$ for convenience in sampling the reaction mixture. The reaction progress for each diglycerol isomer is plotted in Figure 1. From these experiments, it is clear that $\alpha, \alpha$-diglycerol $\alpha, \alpha-1$ is more easily oxidized than $\alpha, \beta$-diglycerol $\alpha, \beta-1$, with their conversion reaching 59 and $39 \%$ after 24 hours, respectively. Interestingly, an initiation period of about 2 hours was observed for both isomers. When the reaction was performed under 3 bar of oxygen, the conversion of $\alpha, \alpha-1$ reached $92 \%$ after 24 hours and no initiation period was observed. 


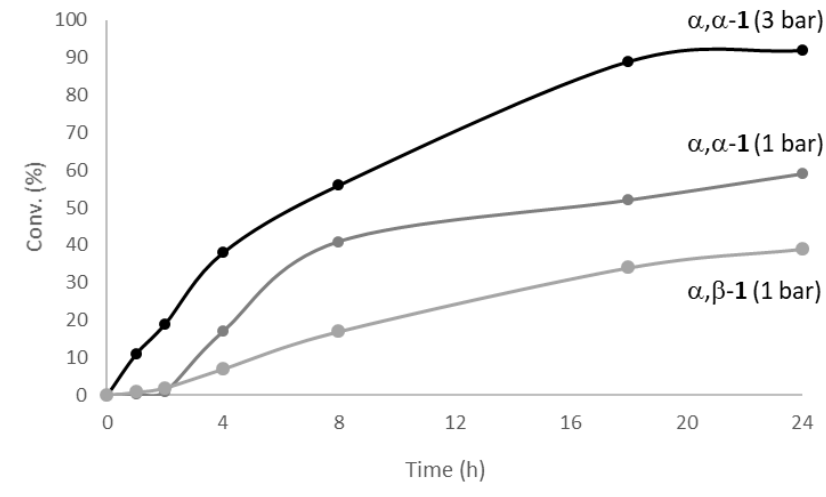

Figure 1. Reaction progress of the oxidation of $\alpha, \alpha$-diglycerol $(\alpha, \alpha-1)$ and $\alpha, \beta$-diglycerol $(\alpha, \beta-1)$. Reaction conditions: $\alpha, \alpha$ - or $\alpha, \beta$-diglycerol (0.45 mmol), Pd-3 (2.5 mol\%), $\mathrm{O}_{2}$ (1 or $3 \mathrm{bar}), \mathrm{HFIP}(5.5 \mathrm{~mL}), 50^{\circ} \mathrm{C}$. The conversions and yields were determined by $\mathrm{GC}$ after derivatization, using methyl oleate as an internal standard.

This result demonstrates that increasing the oxygen pressure has a positive outcome on the overall rate of the reaction. Indeed, increasing the pressure of oxygen increases its concentration in HFIP. Considering that oxygen is necessary to re-oxidize $\operatorname{Pd}(0)$ to $\operatorname{Pd}(\mathrm{II})$ and therefore to complete the catalytic cycle, increasing its concentration allows reaching higher turnover frequencies.

To further understand the formation of the dehydration products, pure $\alpha, \alpha$-diglycerose 3 and $\alpha, \beta$-diglycerose 7 were treated under acidic conditions (Figure 2). After 1 hour at $30^{\circ} \mathrm{C}$, the conversion of 3 and 7 reached 6 and 32\%, respectively, while the yield of 9 and 8 reached 4 and $27 \%$, respectively.<smiles>OCC1COC[C@@](O)(CO)O1</smiles>

3 conv. $=6 \%$

b)<smiles>OC[C@H]1CO[C@@](O)(CO)CO1</smiles>

conv. $=32 \%$

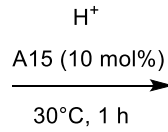

$0^{\circ} \mathrm{C}, 1 \mathrm{~h}$

$\mathrm{HO}$

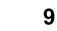

yield $=4 \%$

$\mathrm{H}^{+}$

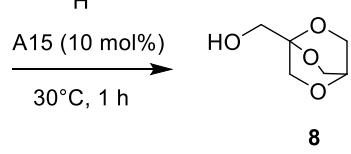

yield $=27 \%$
Figure 2. Dehydration of $\alpha, \alpha$-diglycerose 3 and $\alpha, \beta$-diglycerose 7. Reaction conditions: $\alpha, \alpha$ - or $\alpha, \beta$-diglycerose 3 or 7 ( $0.45 \mathrm{mmol}), \mathrm{A} 15(10 \mathrm{~mol} \%), \mathrm{CH}_{2} \mathrm{Cl}_{2}, 30^{\circ} \mathrm{C}, 2$ hours. The conversions and yields were determined by $\mathrm{GC}$ after derivatization, using methyl oleate as an internal standard.

These results demonstrate that the dehydration of $\alpha, \beta$ diglycerose $\mathbf{7}$ to $\mathbf{8}$ is easier than those of $\alpha, \alpha$-diglycerose $\mathbf{3}$ to 9. They could explain why a high proportion of $\mathbf{8}$ was formed when the reaction was conducted at $50^{\circ} \mathrm{C}$ under 3 bar of oxygen from $\alpha, \beta$-diglycerol, while almost no dehydration product 9 was detected when $\alpha, \alpha$-diglycerol was reacted under the same conditions. To probe the synthetic utility of diglycerose, some chemical transformations were next investigated (Scheme 4). First, $\alpha, \alpha$-diglycerose 3 was treated with Amberlyst 15 for 4 hours to give bicyclic ketal 9 with $48 \%$ isolated yield (Scheme 4, a). Then, benzoylation of $\alpha, \alpha$ diglycerose $\mathbf{3}$ was performed using benzoyl chloride and provided the per-benzoylated products with $74 \%$ combined yield (Scheme $4, b$ ).

$$
\text { (1) yield) }
$$

Scheme 4. Chemical transformations of $\alpha, \alpha$-diglycerose.

In that case, cyclic and linear products 10 and $\mathbf{1 1}$ can be separated and were isolated with 65 and $9 \%$ yield, respectively. Some traces (3\%) of bis-benzoylated diglycerose 12 were also isolated. In order to further confirm the structure of cyclic diglycerose, per-benzoylation was also carried out using 4-bromobenzoyl chloride (Scheme 4, c). Cyclic and linear products 13 and 14 were obtained with 45 and $6 \%$ isolated yields, respectively. Despite our efforts to obtain suitable crystals, no X-Ray structure can be obtained for 13 . Thereby, the structure of compound $\mathbf{1 3}$ was determined by $1 \mathrm{D}$ and $2 \mathrm{D}$ NMR analyses and the relative cis-configuration was assigned though a NOESY experiment (see ESI).

\section{Conclusions}

In conclusion, we have developed the selective catalytic oxidation of diglycerol using a palladium / neocuproine complex and oxygen as a clean oxidant. After optimization of the reaction parameters on $\alpha, \alpha$-diglycerol, the monooxidation product was obtained with high selectivity (99\%) and high yield (93\%). The product was isolated with up to $76 \%$ yield and was found to mainly exist as a cyclic hemi-ketal form. Given its structural similarities with ketoses, this original "ketose-like" compound has been named "diglycerose". The conditions were also applied to $\alpha, \beta$-diglycerol and the corresponding hemi-ketal was obtained with $51 \%$ yield. Finally, $\alpha, \alpha$-diglycerol was used as a platform molecule for benzoylation and dehydration reactions.

\section{Conflicts of interest}

There are no conflicts to declare.

\section{Acknowledgements}


The China Scholarship Council (CSC) is warmly thanked for a Ph.D. grant to H. Wang.

\section{Notes and references}

1 a) A. Corma, S. Iborra, A. Velty, Chem. Rev. 2007, 107, 2411 2502; b) P. Gallezot, Chem. Soc. Rev. 2012, 41, 1538-1558; c) R. A. Sheldon, Green Chem. 2014, 16, 950-963; d) Sheldon, R. A. Green Chem. 2014, 16, 950-963; e) R. Fang, A. Dhakshinamoorthy, Y. Li, H. Garcia, Chem. Soc. Rev. 2020, 49 3638-3687; f) M. Besson, P. Gallezot, C. Pinel, Chem. Rev. 2014, 114, 1827-1870; g) A. J. J. Straathof, Chem. Rev. 2014 114, 1871-1908; h) D. Liu, E. Y.-X. Chen, Green Chem. 2014, 16, 964-981.

2 S. Hu, X. Luo, Y. Li, ChemSusChem, 2014, 7, 66-72; b) 0. Gómez-Jiménez-Aberasturi, J. R. Ochoa-Gómez, J. Chem. Technol. Biotechnol. 2017, 92, 705-711.

3 a) F. Ma, M. A. Hanna, Bioresour. Technol. 1999, 70, 1-15; b) A. Srivastava, R. Prasad, Renewable Sustainable Energy Rev. 2000, 4, 111-113; c) A. Demirbas, Appl. Energy 2011, 88, 1728.

4 a) U. Biermann, W. Friedt, S. Lang, W. Lühs, G. Machmüller, J. O. Metzger, M. Rüsch gen Klaas, H. J. Schäfer, M. P. Schneider, Angew. Chem. Int. Ed. 2000, 39, 2206-2224 Angew. Chem. 2000, 112, 2292-2310; b) U. Biermann, U. Bornscheuer, M. A. R. Meier, J. O. Metzger, H. J. Schäfer, Angew. Chem. Int. Ed. 2011, 50, 3854-3871; Angew. Chem. 2011, 123, $3938-3956$; c) M. A. R. Meier, J. O. Metzger, U. S. Schubert, Chem. Soc. Rev. 2007, 36, 1788-1802; d) Y. Xia, R. C. Larock, Green Chem. 2010, 12, 1893-1909; e) J. M. Fraile, J. I. García, C. I. Herrerías, E. Pires, Synthesis 2017, 49, 14441460.

5 a) D. P. Pfister, Y. Xia, R. C. Larock, ChemSusChem, 2011, 4, 703-717; b) Z. Petrovic, Polym. Rev. 2008, 48, 109-155.

6 a) A. Wolfson, C. Dlugy, Y. Shotland, Environ. Chem. Lett. 2007, 5, 67-71; b) Y. Gu, F. Jérôme, Green Chem. 2010, 12, 1127-1138; c) A. E. Díaz-Álvarez, J. Francos, P. Crochet, V. Cadierno, Curr. Green Chem. 2014, 1, 51-65.

7 a) F. Zeng, X. Yang, D. Li, L. Dai, X. Zhang, Y. Lv, Z. Wie, J. Appl. Polym. Sci. 2020, DOI: 10.1002/APP.48574; b) O. Valerio, M. Misra, A. K. Mohanty, ACS Sustainable Chem. Eng. 2018, 6, 5681-5693; c) O. Valerio, J. M. Pin, M. Misra, A. K. Mohanty, ACS Omega 2016, 1, 1284-1295.

8 a) C. J. A. Mota,; B. Peres Pinto, A. L. de Lima, Glycerol: $A$ Versatile Renewable Feedstock for the Chemical Industry; Springer International Publishing: New York, 2017; b) C. H. Zhou, J. N. Beltramini, Y. X. Fan, G. Q. Lu, Chem. Soc. Rev. 2008, 37, 527-549.

9 a) B. Katryniok, S. Paul, V. Belliere-Baca, P. Rey, F. Dumeignil, Green Chem. 2010, 12, 2079-2098; b) A. Martin, U. Armbruster, H. Atia, Eur. J. Lipid Sci. Technol. 2012, 114, 1023; c) B. Katryniok, S. Paul, F. Dumeignil, ACS Catal. 2013, 3, 1819-1834.

10 a) S. Carrettin, P. McMorn, P. Johnston, K. Griffin, G. J. Hutchings, Chem. Commun. 2002, 7, 696-697; b) S. Chen, P. Qi, J. Chen, Y. Yuan, RSC Adv. 2015, 5, 31566-31574; c) H. Tan, O. E. Tall, Z. Liu, N. Wei, T. Yapici, T. Zhan, M. N. Hedhill, Y. Han, Chem CatChem 2016, 8, 1699-1707.

11 a) Y. Wang, J. Zhou, X. Guo, RSC Adv. 2015, 5, 74611-74628; b) H. Zhao, L. Zheng, X. Li, P. Chen, Z. Hou, Catal. Today, 2020, DOI: 10.1016/j.cattod.2019.03.011.

12 M. O. Sonnati, S. Amigoni, E. P. Taffin de Givenchy, T. Darmanin, O. Choulet, F. Guittard, Green Chem. 2013, 15, 283-306.

13 M. R. Nanda, Y. Zhang, Z. Yuan, W. Qin, H.S. Ghaziaskar, C Xu, Renewable Sustainable Energy Rev. 2016, 56, 1022-1031.

14 M. Sutter, L. Pehlivan, R. Lafon, W. Dayoub, Y. Raoul, E. Métay, M. Lemaire, Green Chem. 2013, 15, 3020-3026; b) M.
Sutter, W. Dayoub, E. Métay, Y. Raoul, M. Lemaire, Chem CatChem 2013, 5, 2893-2904.

15 J. I. García, H. García-Marín, E. Pires, Green Chem. 2014, 16, 1007-1033.

16 D. Ragno, A. Brandolese, D. Urbani, G. Di Carmine, C. De Risi, O. Bortolini, P. P. Giovannini, A. Massi, React. Chem. Eng. 2018, 3, 816-825.

17 a) B. Burczyk, L. Weclas, Tenside Deterg. 1980, 17, 21-24; b) X. Li, L. Wu, Q. Tang, J. Dong, Tenside, Surfactants, Deterg. 2017, 54, 54-63.

18 a) M. Sutter, E. Da Silva, N. Duguet, Y. Raoul, E. Métay, M Lemaire, Chem. Rev. 2015, 115, 8609-8651; b) Z. Fan, Y. Zhao, F. Preda, J.-M. Clacens, H. Shi, L. Wang, X. Feng, F. De Campo, Green Chem. 2015, 17, 882-892.

19 A. Martin, M. Richter, Eur. J. Lipid Sci. Technol. 2011, 113 100-117.

20 a) C. Zhang, H. Wang, Q. Zhou, Green Chem. 2020, 22, 13291337; b) A. C. Law, D. S. Stankowski, B. H. Bomann, S. Suhail, K. H. Salmon, S. W. Paulson, M. J. Carney, N. J. Robertson, J. Appl. Polym. Sci. 2020, DOI: 10.1002/APP.48780; c) D. Dakshinamoorthy, A. K. Weinstock, K. Damodaran, D. F. Iwig, R. T. Mathers, ChemSusChem 2014, 7, 2923-2929.

21 a) J. A. Stewart, B. M. Weckhuysen, P. C. A. Bruijnincx, Catal. Today, 2015, 257 (Part 2), 274-280. b) J. A. Stewart, R Drexel, B. Arstad, E. Reubsaet, B. M. Weckhuysena, P. C. A. Bruijnincx, Green Chem. 2016, 18, 1605-1618.

22 a) J. L. J. van Velthoven, L. Gootjes, D. S. van Es, B. A. J. Noordover, J. Meuldijk, Eur. Polym. J. 2015, 7, 125-135; b) A Bossion, R. H. Aguirresarobe, L. Irusta, D. Taton, H. Cramail, E. Grau, D. Mecerreyes, C. Su, G. Liu, A. J. Müller, H. Sardon, Macromolecules 2018, 51, 5556-5566; c) F. Magliozzi, A. Scali, G. Chollet, D. Montarnal, E. Grau, H. Cramail, ACS Sustainable Chem. Eng. 2020, 8, 9125-9135; d) F. Magliozzi, G. Chollet, E. Grau, H. Cramail, ACS Sustainable Chem. Eng. 2019, 7, 17282-17292.

23 a) L. K. Shrestha, M. Kaneko, T. Sato, D. P. Acharya, T. Iwanaga, H. Kunieda, Langmuir, 2006, 22, 1449-1454; b) L. K. Shrestha, R. G. Shrestha, C. Solans, K. Aramaki, Langmuir, 2007, 23, 6918-6926.

24 a) X. Li, L. Chen, L. Wu, H. Xu, J. Dong, J. Am. Oil Chem. Soc. 2017, 94, 1301-1311; b) Q. Tang, X. Li, J. Dong, ACS Sustainable Chem. Eng. 2018, 6, 16813-16818.

25 M. Sutter, N. Sotto, Y. Raoul, E. Métay, M. Lemaire, Green Chem. 2013, 15, 347-352.

26 M.-C. Duclos, A. Herbinski, A.-S. Mora, E. Metay, M. Lemaire, ChemSusChem 2018, 11, 547-551.

27 a) C. Palomo, M. Oiarbide, J. M. García, Chem. Soc. Rev. 2012, 41, 4150-4164; b) J. Streuff, Synlett 2013, 24, 276280 ; c) N. G. Schmidt, E. Eger, W. Kroutil, ACS Catal. 2016, 6, 4286-4311.

28 L. Daccolti, A. Detomaso, C. Fusco, A. Rosa, R. Curci, J. Org. Chem. 1993, 58, 3600-3601.

29 a) Y. Tsuda, M. Hanajima, N. Matsuhira, Y. Okuno, K. Kanemitsu, Chem. Pharm. Bull. 1989, 37, 2344-2350; b) T. Maki, S. likawa, G. Mogami, H. Harasawa, Y. Matsumura, O. Onomura, Chem. - Eur. J. 2009, 15, 5364-5370.

30 N. D. Vu, B. Guicheret, N. Duguet, E. Metay, M. Lemaire, Green Chem. 2017, 19, 3390-3399.

31 B. Guicheret, Y. Bertholo, P. Blach, Y. Raoul, E. Métay, M Lemaire, ChemSusChem 2018, 11, 3431-3437.

32 R. M. Painter, D. M. Pearson, R. M. Waymouth, Angew. Chem., Int. Ed. 2010, 122, 9646-9649.

33 A. G. De Crisci, K. Chung, A. G. Oliver, D. Solis-lbarra, R. M. Waymouth, Organometallics 2013, 32, 2257-2266.

34 K. Chung, S. M. Banik, A. G. De Crisci, D. M. Pearson, T. R. Blake, J. V. Olsson, A. J. Ingram, R. N. Zare, R. M. Waymouth, J. Am. Chem. Soc. 2013, 135, 7593-7602.

35 K. Chung, R. M. Waymouth, ACS Catal. 2016, 6, 4653-4659.

36 M. Tryznowski, A. Świderska, Z. Żołek-Tryznowska, T. Gołofit, P. G. Parzuchowski, Polymer, 2015, 80, 228-236. 
37 G.-J. ten Brink, I. W. C. E. Arends, M. Hoogenraad, G. Verspui, R. A. Sheldon, Adv. Synth. Catal. 2003, 345, 1341-1352.

38 W. C. Ho, K. Chung, A. J. Ingram, R. M. Waymouth, J. Am. Chem. Soc. 2018, 140, 748-757.

39 Fluorinated solvents such as trifluoroethanol (TFE) and hexafluoroisopropanol (HFIP) are known to well dissolve oxygen. For example, the solubility of oxygen (expressed in $10^{-4} \mathrm{~mol}$ fractions of gas in liquid) at $101.33 \mathrm{kPa}$ partial pressure of gas at $283.15 \mathrm{~K}$, is 9.29 for TFE and 16.37 in HFIP, while it is only 4.26 for methanol. See: a) R. Battino, T. R. Rettich, T. Tominaga, J. Phys. Chem. Ref. Data, 1983, 12, 163 178; b) M. A. Sánchez, A. M. Mainar, J. I. Pardo, M. C. López, J. S. Urieta, Can. J. Chem., 2001, 79, 1460-1465.

40 a) J.-P. Bégué, D. Bonnet-Delpon, B. Crousse, Synlett 2004, 1, 18-29; b) I. Colomer, A. E. R. Chamberlain, M. B. Haughey, T. J. Donohoe, Nat. Rev. Chem. 2017, 1, 0088.

41 I.A. Shuklov, N. V. Dubrovina, A. Börner, Synthesis, 2007, 19, 2925-2943.

42 a) J. Wencel-Delord, F. Colobert, Org. Chem. Front. 2016, 3, 394-400; b) S. K. Sinha, T. Bhattacharya, D. Maiti, React. Chem. Eng. 2019, 4, 244-253.

43 N. R. Conley, L. A. Labios, D. M. Pearson, C.C. L. McCrory, R. M. Waymouth, Organometallics, 2007, 26, 5447-5453.

44 T. T. Wenzel, J. Chem. Soc., Chem. Commun., 1989, 932-933.

45 M. S. Sigman, D. R. Jensen, Acc. Chem. Res., 2006, 39, 221229.

46 S. Cassel, C. Debaig, T. Benvegnu, P. Chaimbault, M. Lafosse, D. Plusquellec, P. Rollin, Eur. J. Org. Chem. 2001, 875-896. 